Aims: Phosphodiesterase 4 (PDE4) inhibitors have been described as potent anti-inflammatory compounds, involving an increase in intracellular levels of cyclic $3^{\prime}, 5^{\prime}$-adenosine monophosphate (AMP). The aim of this study was to compare the effects of selective PDE4 inhibitors, rolipram and RP 73-401 with the cell permeable analogue of cyclic AMP, dibutyryl-cyclic AMP (db-cAMP) and the anti-inflammatory cytokine interleukin-10 (IL-10) on superoxide anion production from peripheral blood mononuclear cells preincubated with lipopolysaccharide (LPS).

Major findings: We report that, after incubation of the cells with LPS, a large increase in superoxide anion production was observed. Rolipram or RP 73-401 $\left(10^{-8}\right.$ to $\left.10^{-5} \mathrm{M}\right)$ induced significant reductions of fMLP-induced superoxide anion production in cells incubated with or without LPS. The db-cAMP $\left(10^{-5}\right.$ to $\left.10^{-3} \mathrm{M}\right)$ also elicited dose-dependent inhibitions of the fMLP-induced superoxide anion production. In contrast, IL-10 (1 or $10 \mathrm{ng} / \mathrm{ml})$ did not elicit a reduction in fMLP-induced superoxide anion production in both conditions.

Principal conclusion: These results suggest that the inhibitory activity of PDE4 inhibitors on fMLPinduced production of superoxide anion production is mediated by db-cAMP rather than IL-10.

Key words: Cyclic AMP, Interleukin 10, Lipopolysaccharide, Mononuclear cells, Phosphodiesterase inhibitors, TNF- $\alpha$

\section{Effects of PDE4 inhibitors on lipopolysaccharide-induced priming of superoxide anion production from human mononuclear cells}

Noëlla Germain ${ }^{1}$, Marianne Corbel' ${ }^{1}$, Chantal Belleguic ${ }^{1,2}$, Elisabeth Boichot ${ }^{1}$ and Vincent Lagente ${ }^{1, C A}$

${ }^{1}$ INSERM U456, Laboratoire de Pharmacodynamie et de Pharmacologie Moléculaire, Faculté des Sciences, Pharmaceutiques et Biologiques, Université de Rennes 1, 2 avenue du Professeur Léon Bernard, 35043 Rennes cedex, France; ${ }^{2}$ Service de Pneumologie, Hôpital de Pontchaillou, CHU de Rennes, 35000 Rennes, France

\footnotetext{
${ }^{\mathrm{CA}}$ Corresponding Author

Tel: $(+33) 299336850$

Fax: (+33) 299336242

E-mail: vincent.lagente@rennes.inserm.fr
}

\section{Introduction}

Increased intracellular levels of the nucleotide cyclic $3^{\prime}, 5^{\prime}$-adenosine monophosphate (cyclic AMP) and the subsequent activation of cyclic AMP-dependent protein kinase (PKA) in both the respiratory smooth muscle and inflammatory cells result in bronchodilation, reduction of inflammation and immunomodulatory activities. ${ }^{1}$ The intracellular concentration of cyclic nucleotides is mainly determined by the activation of adenylyl cyclase coupled with adrenoceptor and G-protein, and by the breakdown of cyclic nucleotide by phosphodiesterases (PDEs). PDEs are a family of enzymes that hydrolyze the 3 '-ribose phosphate bond of the naturally occurring second messenger nucleotide $3^{\prime}, 5^{\prime}$-cyclic monophosphate to form biologically inert $5^{\prime}$-nucleotide monophosphate. PDEs are, at present, divided into at least seven families, each with distinct substrate specificities and regulatory characteristics. ${ }^{1}$ Among these families, PDE3 and PDE4 are responsible for cAMP hydrolysis; however, PDE4 is mainly present in the inflammatory cells. Therefore, selective type 4 phosphodiesterase inhibitors are able to elicit an increase in intracellular
cAMP content. Due to their potent anti-inflammatory activity, the interest in selective PDE 4 inhibitors in the treatment of pulmonary inflammatory disorders has been greatly increasing for the past few years (for reviews, see References 2 and 3).

We previously demonstrated that PDE4 inhibitors are able to reduce the fMLP-induced arachidonate release from human mononuclear cells. ${ }^{4}$ Nevertheless, this release was not associated with an increase in cyclic AMP in human mononuclear cells. ${ }^{4}$ Moreover, PKA inhibitors did not reduce the inhibitory activity of selective PDE4 inhibitors on arachidonate and tumor necrosis factor-alpha (TNF- $\alpha$ ) release from monocytes, ${ }^{5,6}$ suggesting that other mechanisms are involved in the anti-inflammatory activity of selective PDE4 inhibitors. Hence, the effect of PDE4 inhibitors appeared to be partly mediated through the release of the anti-inflammatory cytokine, interleukin 10 (IL10), ${ }^{7,8}$ which controls the formation of pro-inflammatory cytokine such as TNF- $\alpha$.

The aim of this study was to compare the effects of two selective PDE4 inhibitors (rolipram and RP 73-401) with the cell-permeable analog of cyclic AMP, dibutyryl-cyclic AMP (db-cAMP) and IL-10 on 
fMLP-induced chemiluminescence in peripheral blood mononuclear cells (PBMC) preincubated in lipopolysaccharide (LPS) as a model of cellular hyperreactivity.

\section{Materials and methods}

\section{Preparation of PBMC}

Mononuclear cells were isolated from buffy coats (CRTS Rennes, France) obtained from healthy donors by density gradient centrifugation $(20 \mathrm{~min}$ at $1100 \times g)$ on Ficoll-Hypaque. Cells recovered at the interface were washed twice with phosphate-buffered saline without $\mathrm{Ca}^{2+}$ and $\mathrm{Mg}^{2+}$ (PBS). Mononuclear cells were resuspended in RPMI 1640 supplemented with L-glutamine $(2 \mathrm{mM})$, penicillin $(100 \mathrm{U} / \mathrm{ml})$ and streptomycin $(100 \mathrm{~g} / \mathrm{ml})$, and $10 \%$ heat-inactivated fetal calf serum (RPMI-FCS). The cells were counted and assessed for viability by Trypan blue exclusion. Under these conditions, the viability of cells exceeded 95\%.

\section{Protocol and drug treatments}

Cell concentration was adjusted to $10^{6}$ cells $/ \mathrm{ml}$ in RPMI containing streptomycin $(10 \mathrm{UI} / \mathrm{ml})$, glutamin $(2 \mu \mathrm{mol} / \mathrm{ml})$ and penicillin $(10 \mu \mathrm{g} / \mathrm{ml})$. The cell suspensions were then placed at $4^{\circ} \mathrm{C}$ for $2 \mathrm{~h}$. After this period, the cells were incubated with LPS $(10 \mu \mathrm{g} / \mathrm{ml})$ or vehicle, for $30 \mathrm{~min}$ at $37^{\circ} \mathrm{C}$.

Then, the cells were incubated either with rolipram $\left(10^{-8}, 10^{-7}, 10^{-6}\right.$ or $\left.10^{-5} \mathrm{M}\right)$ or RP $73-401\left(10^{-8}, 10^{-7}\right.$, $10^{-6}$ or $\left.10^{-5} \mathrm{M}\right)$ or db-cAMP $\left(10^{-5}, 10^{-4}\right.$ or $\left.10^{-3} \mathrm{M}\right)$ or IL10 ( 1 and $10 \mathrm{ng} / \mathrm{ml}$ ) or vehicle, for $30 \mathrm{~min}$ at $37^{\circ} \mathrm{C}$.

For each set of experiments, $n$ represents the number of subjects. For each subject, the experiments using cells treated or not with LPS were carried out in triplicate.

\section{Superoxide anion production}

Immediately after the compound or vehicle treatments, peaks of maximum luminol-dependent chemiluminescence technique (LDCL) (expressed in relative light units (RLU)) after fMLP stimulation $\left(10^{-6} \mathrm{M}\right)$ were measured on a Beckman counter on 200000 cells in the presence of $700 \mu 1$ of a luminol solution $(0.02 \mathrm{mg} / \mathrm{ml})$ (modified from Reference 9).

For kinetic study, cells were only incubated with LPS or vehicle and RLU were measured every $30 \mathrm{sec}$, $1.5 \mathrm{~min}$ before and $3.5 \mathrm{~min}$ after FMLP stimulation, using repeated measures on the same set of experiments of different subjects.

\section{Statistical analysis}

All results are expressed as means \pm SEM. Statistical differences were assessed using the analysis of variance and Student's $t$-test. $P<0.05$ was accepted as being significant. For the kinetic study, the curves were compared using two-way analysis of variance.

\section{Drugs and chemicals}

The following drugs were used: Ficoll-Hypaque (Pharmacia, Upsala, Sweden), PBS, RPMI 1640, glutamine, penicillin and streptomycin (Gibco, Cergy-Pontoise, France), FCS (Flow Laboratories, Irvine, UK), dimethysulfoxide (DMSO), db-cAMP, 5-amino-2,3-dihydro1,4-phthalazinedione (luminol), $N$-formyl-Met-Leu-Phe (fMLP) and LPS from Escherichia coli (0.55 B5) (Sigma, St. Louis, MO, USA), and IL-10 (R\&D systems, Minneapolis, MN, USA). Luminol solution was obtained from a basal solution of $2 \mathrm{mg} / \mathrm{ml}$ in DMSO stored at $-20^{\circ} \mathrm{C}$ and dissolved in PBS buffer before LDCL experiments. Rolipram was a generous gift from Dr J.M. Planquois (Institut de Recherche Jouveinal/ Parke-Davis, Fresnes, France) and RP 73401 was a generous gift from Dr J.J. Bourguignon (Faculté de Pharmacie, Illkirch, France). They were first dissolved in $0.1 \%$ DMSO and then diluted in RPMI supplemented with $0.2 \%$ fatty acid free bovine serum albumin. Vehicle controls were included in the experimental design.

\section{Results}

\section{Time-course of the fMLP-induced LDCL}

As shown in Figure 1, there is no change in the LDCL between LPS-treated or control cells before the stimulation with fMLP. After $1.5 \mathrm{~min}$ of stable basal level in LDCL, the cells were stimulated with $1 \mu \mathrm{M}$ of fMLP and a marked increase in the production of RLU was noted. However, after incubation of the cells with LPS, a large increase in LDCL was observed in comparison with control (non-treated cells) (Fig. 1). The maximum LDCL was observed at $3 \mathrm{~min}$ after the beginning of the experiment, i.e. $1.5 \mathrm{~min}$ after the stimulation with fMLP, whether or not the cells were treated with LPS.

Addition of superoxide dismutase (100 or $300 \mathrm{IU}$ ) to fMLP-stimulated cells induced a 50 and 90\% LDCL decrease, respectively, whether or not the cells were treated with LPS (data not shown). This result demonstrates that most reactive oxygen species released from cells and measured by LDCL are superoxide anions.

Effects of rolipram and RP 73-401 on superoxide anion production from PBMC

When the cells were incubated with rolipram $\left(10^{-8}\right.$ to $\left.10^{-5} \mathrm{M}\right)$ or $\mathrm{RP} 73-401\left(10^{-8}\right.$ to $\left.10^{-5} \mathrm{M}\right)$, a reduc- 


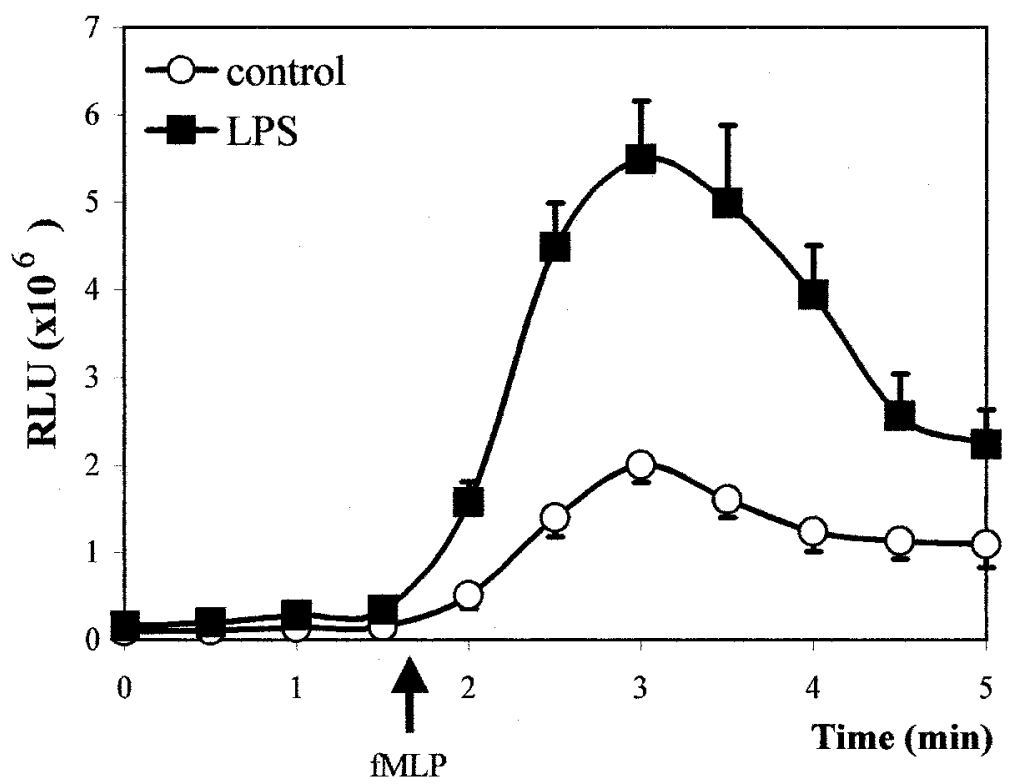

FIG. 1. Time-course of the superoxide anion production from human peripheral blood mononuclear cells in the absence (control) or presence of lipopolysaccharide (LPS) $(10 \mu \mathrm{g} / \mathrm{ml}$ for $30 \mathrm{~min})$. Superoxide anion production was measured by the luminol-dependent chemiluminescence technique (expressed in relative light units (RLU)). Superoxide anion production was measured every $30 \mathrm{sec}, 1.5 \mathrm{~min}$ before and $3.5 \mathrm{~min}$ after fMLP $(1 \mu \mathrm{M})$ stimulation. The whole curves were compared using twoway analysis of variance $(p<0.001, n=5-6)$.

tion of fMLP-induced superoxide anion production was observed (Fig. 2). Maximal inhibitions were observed at $10^{-6} \mathrm{M}$ rolipram and $10^{-7} \mathrm{M}$ RP 73-401.

After stimulation of the cells with LPS, the superoxide anion production induced by fMLP was markedly enhanced. In this condition, rolipram and RP 73-401 also elicited reduction of superoxide anion production (Fig. 2). These inhibitory effects were significant from $10^{-7} \mathrm{M}$ rolipram and $10^{-8} \mathrm{M} \mathrm{RP}$ 73-401, and maximal inhibitions were observed at these concentrations.

\section{Effects of db-cAMP on superoxide anion production from PBMC}

When the cells were incubated with db-cAMP, a dosedependent inhibition of the fMLP-induced superoxide anion production was also observed (Fig. 3). This inhibitory effect was similar whether the cells were incubated or not with LPS, since the effect appeared significantly from $10^{-4} \mathrm{M}$ db-cAMP.

\section{Effects of IL-10 on superoxide anion production from PBMC}

Incubation of PBMC with IL-10 (1 or $10 \mathrm{ng} / \mathrm{ml}$ ) for $30 \mathrm{~min}$ did not elicit a reduction in fMLP-induced superoxide anion production, whether or not the cells were treated with LPS (Fig. 4).

\section{Discussion}

The major finding of this study was that the selective PDE4 inhibitors rolipram and RP 73-401, as well as the PKA activator db-cAMP, but not IL-10, were able to reduce the much enhanced superoxide anion production of PBMC primed with LPS and thus stimulated with fMLP.

In the present study, we presented an in vitro model of enhanced reactivity of the human PBMC following incubation with LPS. This enhanced response is observed using the chemiluminescence technique that is mainly stimulated by superoxide production under the stimulation of the cells with fMLP.

Lipopolysaccharides are potent and pleiotropic stimuli for cells of the immune system. Stimulation of leucocytes by LPS leads to the release of cytokines and inflammatory mediators that enhance host defense against microorganisms. ${ }^{10}$ Priming is considered to result from exposure to a low concentration of an agent, which itself has little or no effect on function but that allows a second agent to provoke a response that is larger than the non-primed response. $^{11}$ Such a priming has been previously observed for the release of 5-lipoxygenase metabolites from PBMC. ${ }^{12}$

The mechanism of LPS-dependent priming is not completely understood. However, it has been reported that TNF- $\alpha$ released from monocytes stimulated with endotoxin is a potent primer of oxidative activity. ${ }^{13}$ Regarding the superoxide anion produc- 

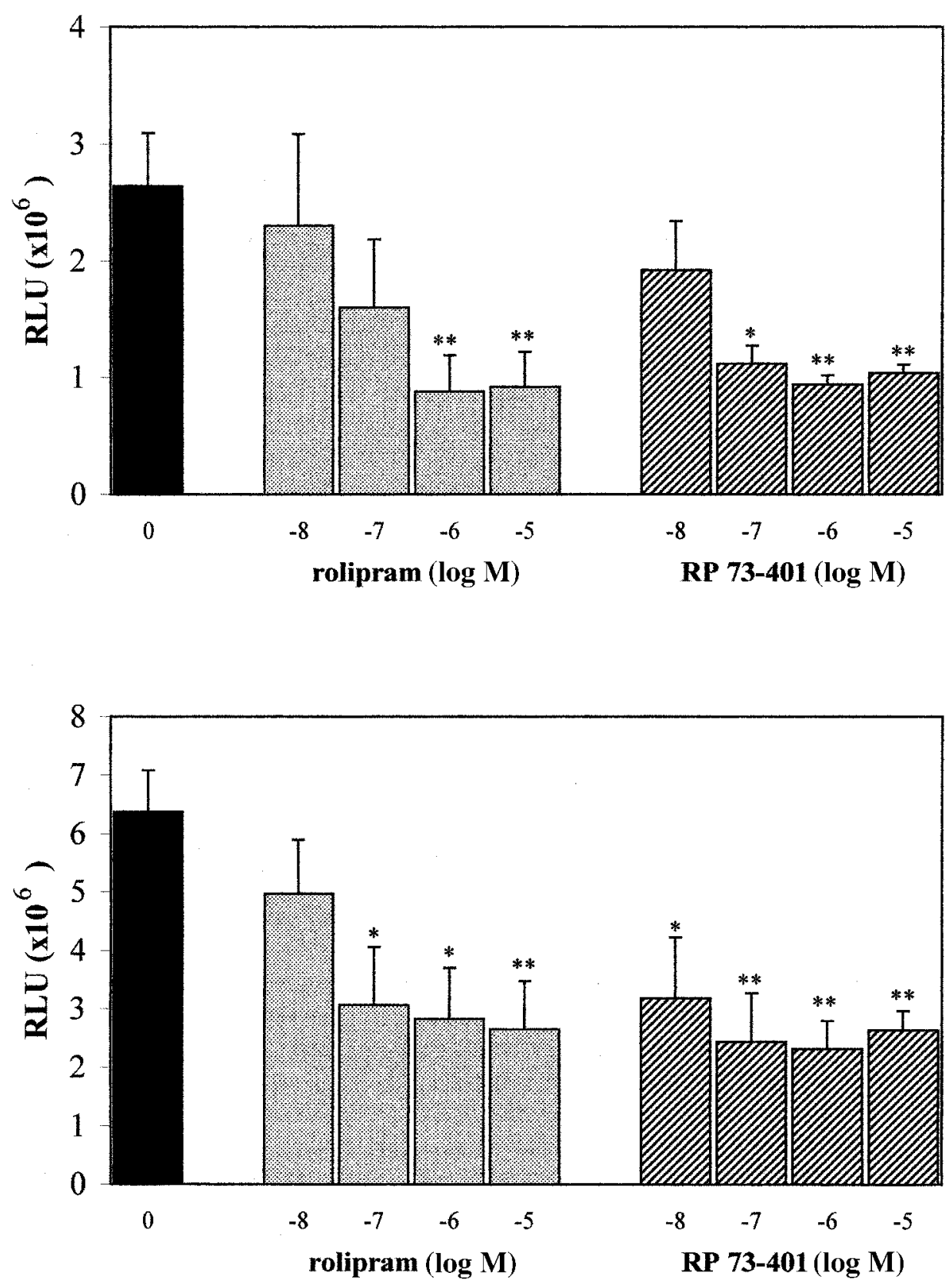

FIG. 2. Effects of rolipram $\left(10^{-8}\right.$ to $\left.10^{-5} \mathrm{M}\right)$, RP $73-401\left(10^{-8}\right.$ to $\left.10^{-5} \mathrm{M}\right)$, or vehicle on $\mathrm{fMLP}$-induced increased in superoxide anion production (expressed in relative light units (RLU)) from peripheral blood mononuclear cells pretreated (lower panel) or not (upper panel) with lipopolysaccharide $(10 \mu \mathrm{g} / \mathrm{ml}$ for $30 \mathrm{~min}) .{ }^{*} p<0.05,{ }^{* *} p<0.01$ in comparison with non-treated (control) cells $(n=5-6)$.

tion, it was proposed that LPS priming process represents cellular and/or biochemical alterations that increase the efficiency of NADPH oxidase assembly and the subsequent generation of superoxide anion. ${ }^{14}$

Selective PDE4 inhibitors have been largely demonstrated to possess in vitro and in vivo anti-inflammatory activity. ${ }^{2,3,15}$ For this, they also demonstrated the inhibition of the release of cytokines and arachidonic acid metabolites from resident or recruited inflammatory cells in airways. ${ }^{15}$ Moreover, these compounds are able to diminish the reactive oxygen species from various cell types such as eosinophil, ${ }^{16-18}$ neutrophil, ${ }^{19,20}$ and peritoneal macrophages. ${ }^{21}$

In the present study, we observed a dose-dependent inhibition by rolipram and RP 73-401 on fMLPinduced superoxide anion production in the absence or presence of pretreatment of cells with LPS. Maximal inhibitions were obtained at $10^{-6} \mathrm{M}$ rolipram and $10^{-7} \mathrm{M}$ RP 73-401 in the absence of incubation of the cells with LPS and $10^{-7} \mathrm{M}$ rolipram and $10^{-8} \mathrm{M}$ RP 73-401 in the experiments with LPS. This indicates that RP 73-401 was more potent than rolipram in the inhibition of superoxide anion production. This result 

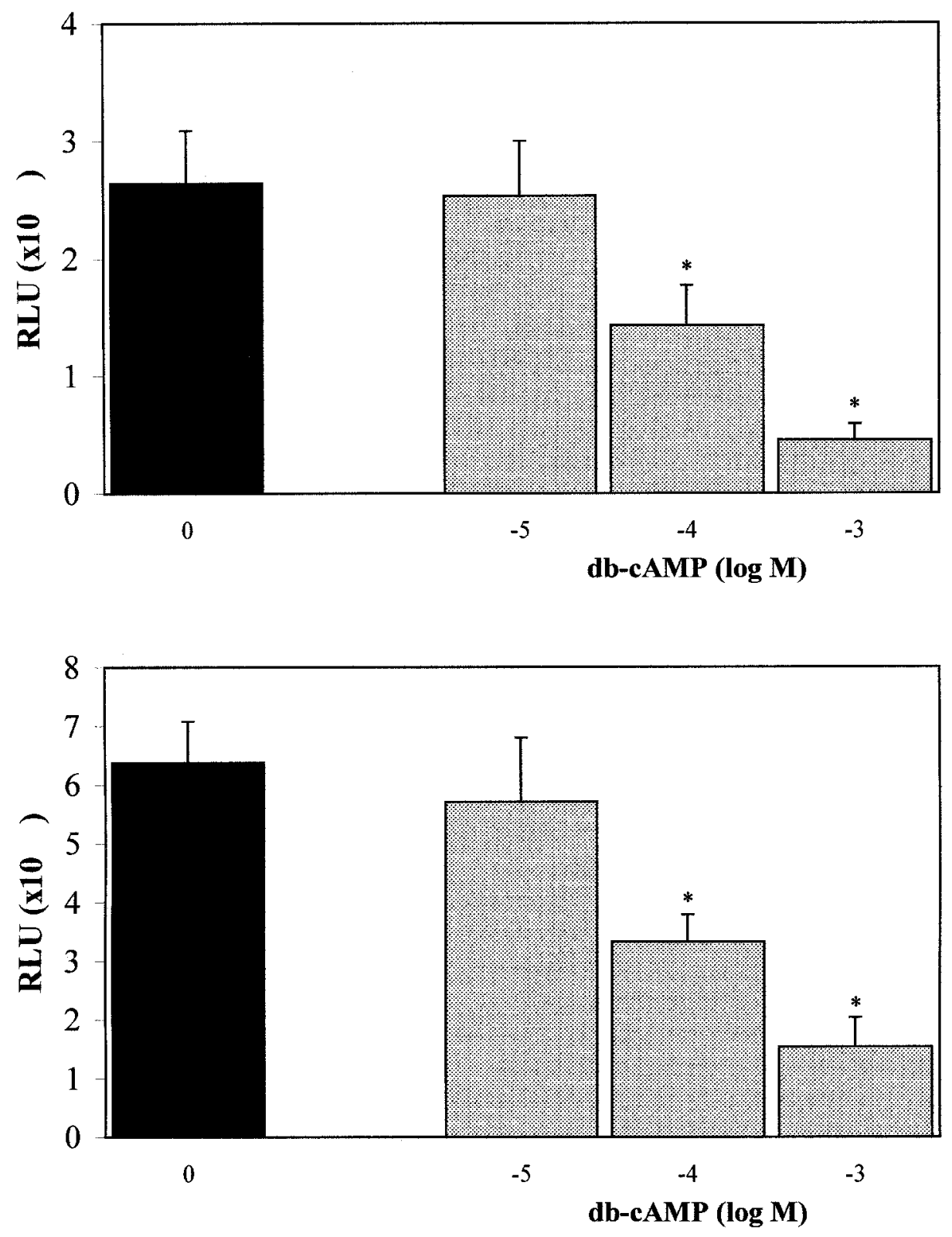

FIG. 3. Effects of dibutyryl-cyclic AMP (db-cAMP) $\left(10^{-5}\right.$ to $\left.10^{-3} \mathrm{M}\right)$ or vehicle on fMLP-induced increased in superoxide anion production (expressed in relative light units (RLU)) from peripheral blood mononuclear cells pretreated (lower panel) or not (upper panel) with lipopolysaccharide. ${ }^{*} p<0.05,{ }^{*} p<0.01$ in comparison with non-treated (control) cells $(n=5-6)$.

is consistent with the study of Souness et al., ${ }^{22}$ showing that rolipram was approximately 2600 -fold less potent than RP 73-401 against pig aortic smooth muscle PDE 4 and about 25 times less potent against eosinophil PDE4. Interestingly, the inhibitory effects of RP 73-401 for the reduction of fMLP-induced chemiluminescence is similar to that which has been observed for the inhibition of fMLP-induced arachidonate release from mononuclear cells. ${ }^{23}$ In this latter study, we also proposed that the PDE4 isoenzyme inhibition represents the main mechanism, leading to the arachidonate release from mononuclear cells, in contrast to the reduction of TNF- $\alpha$ release. Such a mechanism of action has been previously reported for the inhibition of superoxide anion production by guinea-pig eosinophils. ${ }^{24}$ Moreover, the $\mathrm{IC}_{50}$ of the RP 73-401 for the inhibition of LPS-induced TNF- $\alpha$ release is also markedly lower $(0.7 \mathrm{nM}) .{ }^{23}$ The mechanism by which RP 73-401 presents a more potent anti-inflammatory activity when the cells are stimulated with LPS is presently unknown. One possible explanation is that additional mechanisms may be required instead of the sole inhibition of PDE4 isoenzyme and the increase in intracellular cyclic AMP.

We therefore analyzed the effects of a cell-permeable analog of cyclic AMP, db-cAMP. In our hands, dbcAMP was able to dose-dependently inhibit the fMLP- 

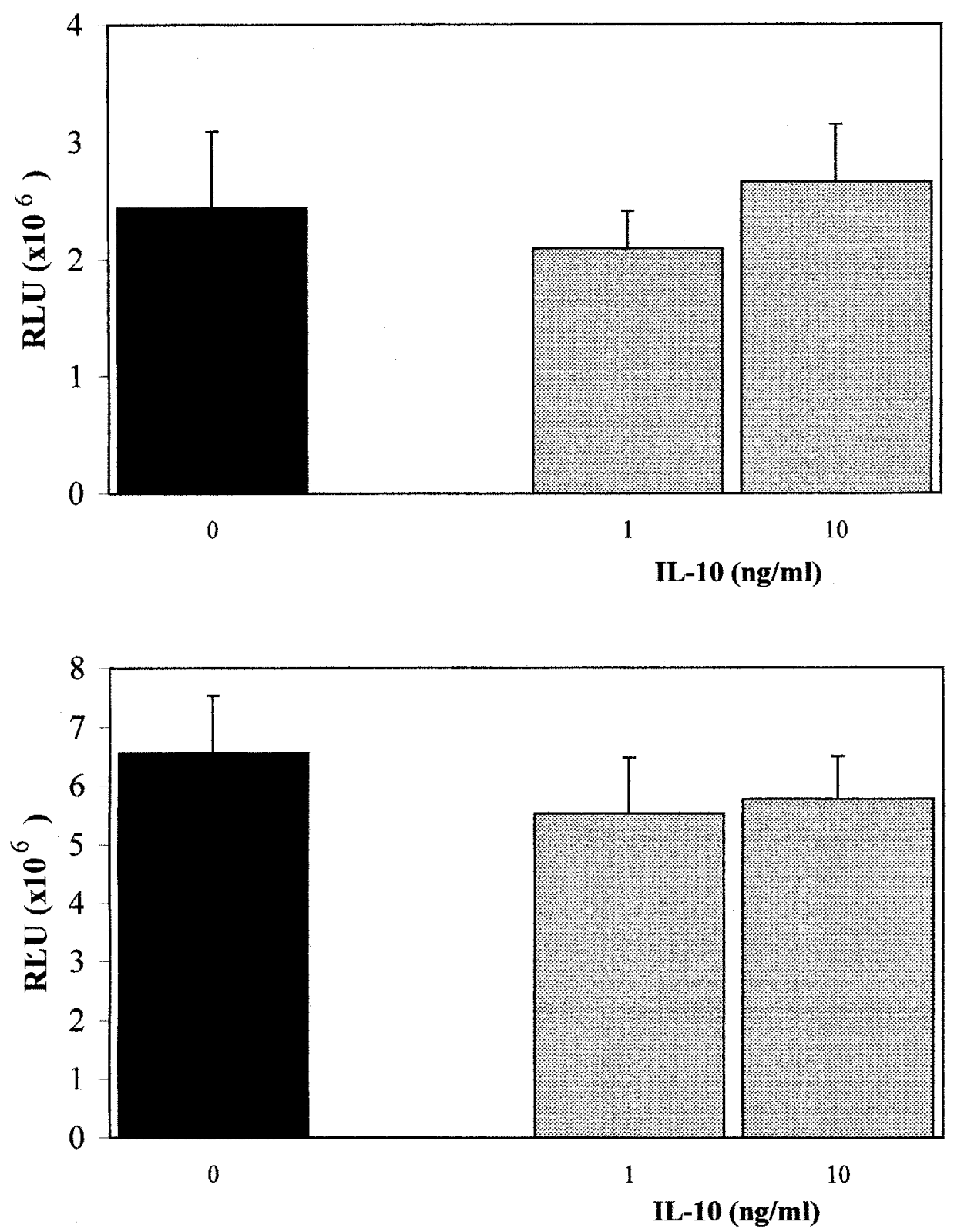

FIG. 4. Effects of interleukin 10 (IL-10) $(1$ and $10 \mathrm{ng} / \mathrm{ml})$ or vehicle on fMLP-induced increased in superoxide anion production (expressed in relative light units (RLU)) from peripheral blood mononuclear cells pretreated (lower panel) or not (upper panel) with lipopolysaccharide $(n=3)$.

induced superoxide anion production, whether or not the cells were incubated with LPS. We have previously demonstrated that the inhibition of arachidonate release from human mononuclear cells by selective PDE4 inhibitors is not associated with a significant increase in intracellular cyclic AMP. ${ }^{4}$ Furthermore, the fact that incubation of the cells with cyclic AMP-dependent protein kinase (PKA) inhibitors does not elicit a reduction of the in vitro antiinflammatory activities of selective PDE 4 inhibitors ${ }^{5,6}$ suggested that other mechanisms than intracellular cyclic-AMP enhancement and PKA activation must be considered. Interestingly, Kambayashi et al. $^{7}$ have reported that rolipram can induce IL-10 release, and that IL-10 is responsible for some inhibition of TNF- $\alpha$ release. In our hands, IL-10 did not elicit significant inhibition of fMLP-induced production of superoxide anion whether or not the cells were treated with fMLP. This result is consistent with the study of Bussolati et al. ${ }^{25}$ demonstrating that IL-10 did not reduce the early superoxide anion production by monocyte or polymorphonuclear neutrophils challenged with LPS, but was also able to enhance their synthesis. These results suggest that the inhibitory activity of PDE4 inhibitors on fMLP-induced production of superoxide anion production is mediated by db-cAMP rather than IL-10. In contrast, the inhibitory activity of PDE 4 inhibitors on TNF- $\alpha$ release and neutrophilia in rats treated with LPS may be mediated by IL-10 rather than by cyclic-AMP. ${ }^{26}$ 


\section{Conclusion}

In conclusion, we report that incubation with LPS elicits a priming effect on the fMLP-induced superoxide anion production. Furthermore, the selective PDE4 inhibitors, rolipram and RP 73-401, as well as the cell permeable analog of cyclic-AMP (db-cAMP), but not IL-10, markedly reduced the fMLP-induced superoxide anion production in the presence or absence of the incubation of the cells with LPS. These results suggest that the inhibitory activity of PDE4 inhibitors on fMLP-induced production of superoxide anion production is mediated by db-cAMP rather than IL-10.

ACKNOWLEDGEMENTS. This study was funded by INSERM/FIOCRUZ Marianne Corbel is a recipient of a fellowship from the Conseil Régional de Bretagne.

\section{References}

1. Beavo JA, Conti M, Heaslip RJ. Multiple cyclic nucleotides phosphodiesterases. Mol Pharmacol 1994; 46: 399-405.

2. Barnette MS. Phosphodiesterase 4 (PDE4) inhibitors in asthma and chronic obstructive pulmonary disease (COPD). Prog Drug Res 1999; 53: $193-229$.

3. Souness JE, Aldous D, Sargent C. Immunosuppressive and anti-inflammatory effects of cyclic AMP phosphodiesterase (PDE) type 4 inhibitors. Immunopharmacol 2000; 47: 127-162.

4. Hichami A, Boichot E, Germain N, Legrand A, Moodley I, Lagente V. Involvement of cyclic AMP in the effects of phosphodiesterase IV inhibitors on arachidonate release from mononuclear cells. Eur $J$ Pharmacol 1995; 291: 91-97.

5. Hichami A, Boichot E, Germain N, Berdychev E, Coqueret O, Lagente V. Phosphodiesterase 4 inhibitors and db-cAMP inhibit TNF- $\alpha$ release from human mononuclear cells. Effects of cAMP and cGMP-dependent protein kinase inhibitors. Med Inflamm 1996; 5: 425-428.

6. Hichami A, Boichot E, Germain N, Coqueret O, Lagente V. Interactions between cAMP and cGMP dependent protein kinase inhibitors and phosphodiesterase IV inhibitors on arachidonate release from human monocytes. Life Sci 1996; 59: 255-261.

7. Kambayashi T, Jacob CO, Zhou D, Mazurek N, Fong M, Strassmann G. Cyclic nucleotide phosphodiesterase type IV participates in the regulation of IL-10 and in the subsequent inhibition of TNF-alpha and IL-6 release by endotoxin-stimulated macrophages. J Immunol 1995; 155: 4909-4916.

8. Eigler A, Siegmund B, Emmerich U, Baumann KH, Hartmann G, Endres S. Anti-inflammatory activities of cAMP-elevating agents: enhancement of IL-10 synthesis and concurrent suppression of TNF production. J Leukoc Biol 1998; 63: 101-107.

9. Trevithick JR, Dzialoszynski T. A new technique for enhancing luminol luminescent detection of free radicals and reactive oxygen species. Biochem Mol Biol Int 1994; 33: 1179-1190.

10. Morrison DC, Ryan JL. Bacterial endotoxins and host immune responses. Adv Immunol 1979; 28, 293-450.

11. Macari DM, Teixeira MM, Hellewell PG. Priming of eosinophil recruitment in vivo by LPS pretreatment. J Immunol 1996; 157: 1684-1692.
12. Surette ME, Nadeau M, Borgeat $P$, Gosselin J. Priming of human peripheral blood mononuclear cells with lipopolysaccharides for enhanced arachidonic acid release and leukotriene synthesis. J Leukoc Biol 1996; 59: 709-715.

13. Tennenberg SD, Solomkin JS. Activation of neutrophils by cachectin/ tumor necrosis factor: priming of $N$-formyl-methionyl-leucyl-phenylalanine-induced oxidative responsiveness via receptor mobilization without degranulation. J Leukoc Biol, 1990; 47: 217-223.

14. DeLeo FR, Renee J, McCormick S, Nakamura M, Apicella M, Weiss JP, Nauseef WM. Neutrophils exposed to bacterial lipopolysaccharide upregulate NADPH oxidase assembly. J Clin Invest 1998; 101: $455-463$.

15. Teixeira MM, Gristwood RW, Cooper N, Hellewell PG. Phosphodiesterase (PDE) 4 inhibitors: anti-inflammatory drugs of the future? Tips 1997; 18: 164-170.

16. Dent G, Giembycz MA, Rabe KF, Barnes PJ. Inhibition of eosinophil cyclic nucleotide PDE activity and opsonised zymosan-stimulated respiratory burst by 'type IV'-selective PDE inhibitors. Br J Pharmacol 1991; 103: 1339-1346.

17. Souness JE, Carter CM, Diocee BK, Hassall GA, Wood LJ, Turner NC. Characterization of guinea-pig eosinophil phosphodiesterase activity. Assessment of its involvement in regulating superoxide generation. Biochem Pharmacol 1991; 42: 937-945.

18. Barnette MS, Manning CD, Cieslinski LB, Burman M, Christensen SB, Torphy TJ. The ability of phosphodiesterase IV inhibitors to suppress superoxide production in guinea pig eosinophils is correlated with inhibition of phosphodiesterase IV catalytic activity. J Pharmacol Exp Ther 1995; 273: 674-679.

19. Nielson CP, Vestal RE, Sturm RJ, Heaslip R. Effects of selective phosphodiesterase inhibitors on the polymorphonuclear leukocyte respiratory burst. J Allergy Clin Immunol 1990; 86: 801-808.

20. Sullivan GW, Carper HT, Mandell GL. The specific type IV phosphodiesterase inhibitor rolipram combined with adenosine reduces tumor necrosis factor-alpha-primed neutrophil oxidative activity. Int J Immunopharmacol 1995; 17: 793-803.

21. Turner NC, Wood LJ, Burns FM, Gueremy T, Souness JE. The effect of cyclic AMP and cyclic GMP phosphodiesterase inhibitors on the superoxide burst of guinea-pig peritoneal macrophages. BrJ Pharmacol 1993; 108: 876-883.

22. Souness JE, Maslen C, Webber S, Foster M, Raeburn D, Palfreyman MN, Ashton MJ, Karlsson JA. Suppression of eosinophil function by RP 73401, a potent and selective inhibitor of cyclic AMP-specific phosphodiesterase: comparison with rolipram. Br J Pharmacol 1995; 115: 39-46.

23. Boichot E, Wallace JL, Germain N, Corbel M, Lugnier C, Lagente V, Bourguignon JJ. Anti-inflammatory activities of a new series of selective phosphodiesterase 4 inhibitors derived from 9-benzyladenine. J Pbarmacol Exp Ther 2000; 292: 647-653.

24. Barnette MS, Manning CD, Cieslinski LB, Burman M, Christensen SB, Torphy TJ. The ability of phosphodiesterase IV inhibitors to suppress superoxide production in guinea pig eosinophils is correlated with inhibition of phosphodiesterase IV catalytic activity. J Pharmacol Exp Ther 1995; 273: 674-679.

25. Bussolati B, Mariano F, Montrucchio G, Piccoli G, Camussi G. Modulatory effect of interleukin-10 on the production of platelet-activating factor and superoxide anions by human leucocytes. Immunology 1997; 90: 440-447.

26. Escofier N, Boichot E, Germain N, e Silva PM, Martins MA, Lagente V. Effects of interleukin-10 and modulators of cyclic AMP formation on endotoxin-induced inflammation in rat lung. Fundam Clin Pharmacol 1999; 13: 96-101.

Received 2 April 2001; accepted 18 April 2001 


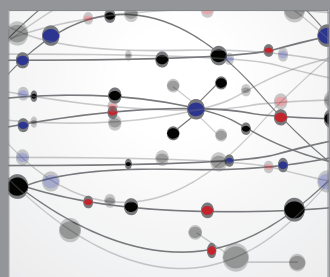

The Scientific World Journal
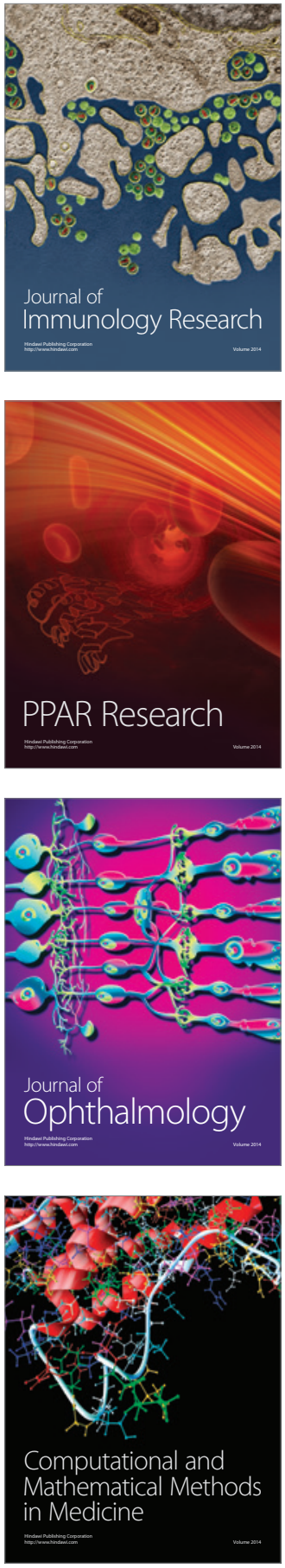

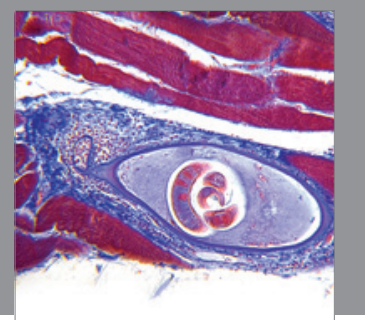

Gastroenterology

Research and Practice
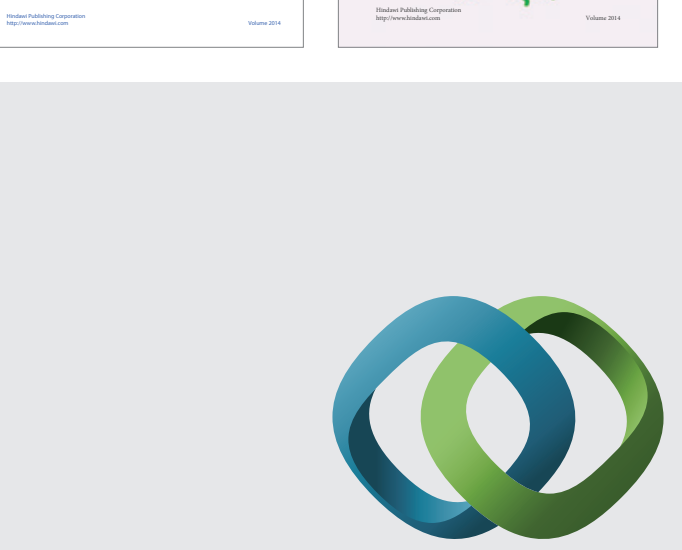

\section{Hindawi}

Submit your manuscripts at

http://www.hindawi.com
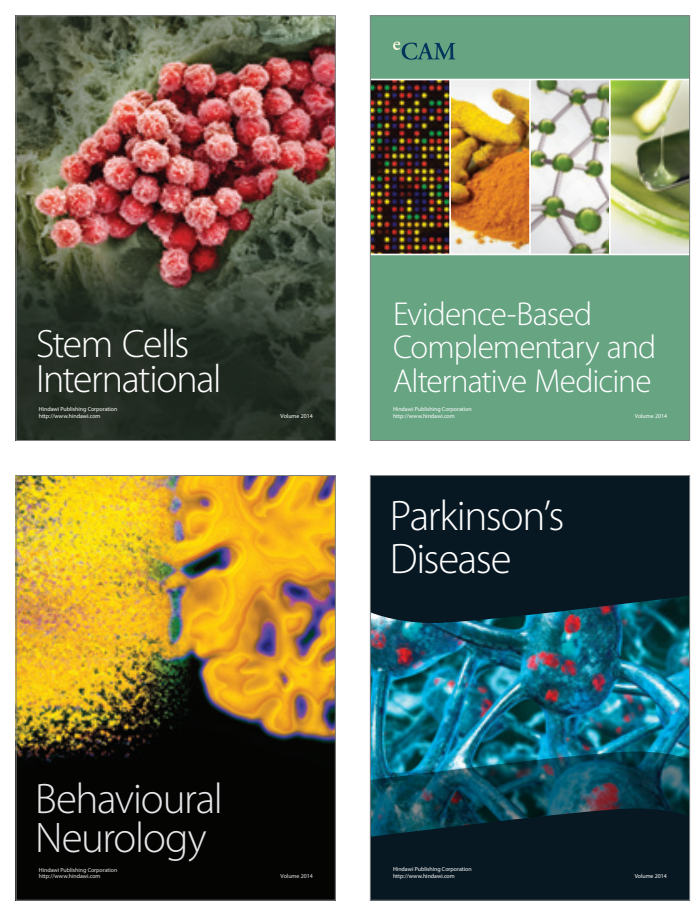

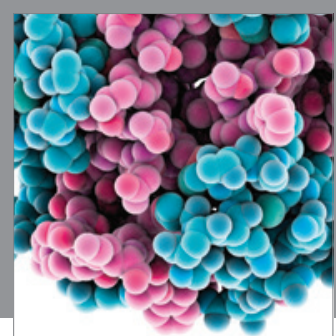

Journal of
Diabetes Research

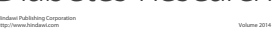

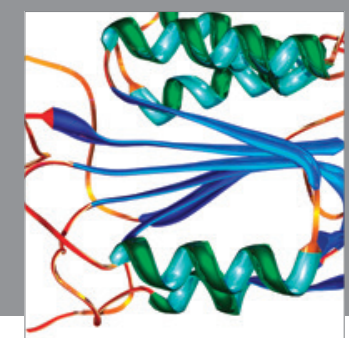

Disease Markers
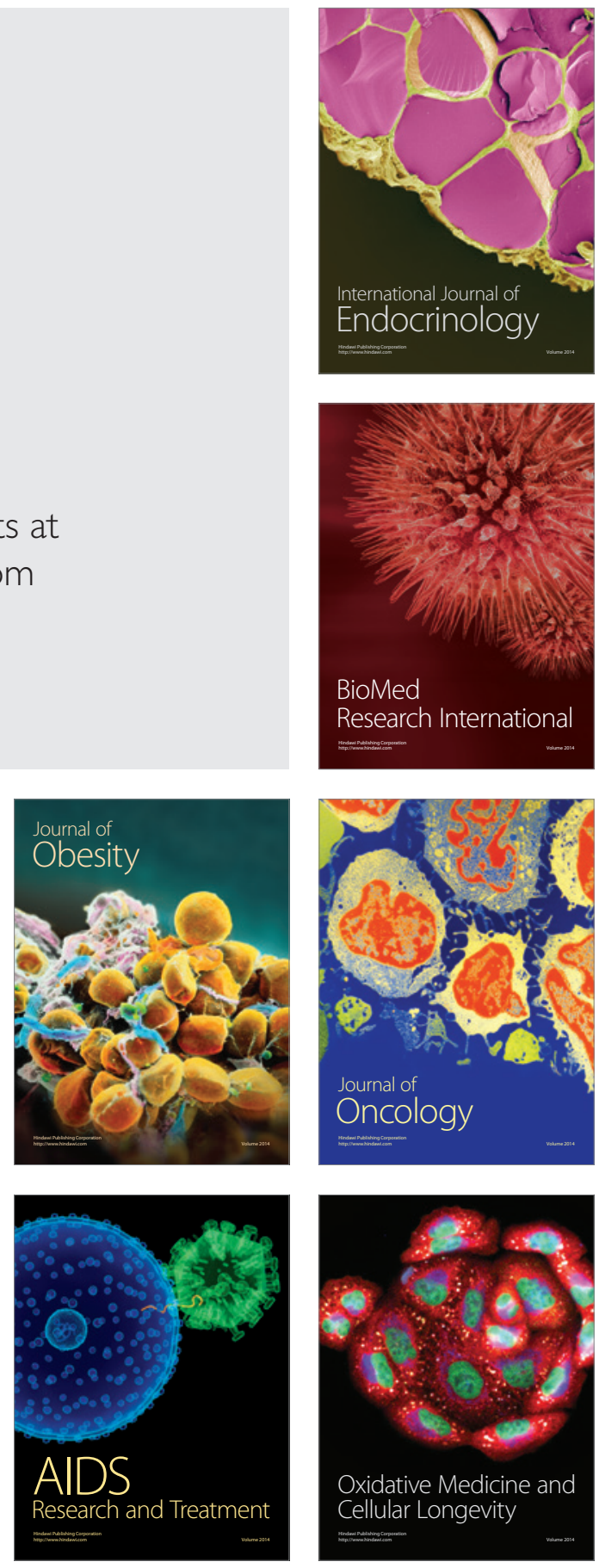